\title{
CHARLOTTE PERKINS GILMAN AND THE WHITMAN CONNECTION
}

\author{
JOANN P. KRIEG
}

SinCE THE REDISCOVERY in the past decade of Charlotte Perkins Gilman's short story "The Yellow Wall-Paper," Gilman's name has once again come to the fore. Certainly the best piece of fiction she ever produced, the story has earned for its author a reputation almost as great as that which she enjoyed in her own lifetime. That reputation, though far-reaching, was mixed; for Gilman, whose literary output ranged far beyond "The Yellow Wall-Paper," was well known early in this century as an ardent feminist socialist. Her treatise on Women and Economics (1898) is a textbook of the effects on nineteenth-century womanhood of industrial capitalism, and her attack on The Home (1903) offered a plan for women's economic independence that would take them into fields of labor outside the home, leaving their children in the care of others.

This is the same Charlotte Perkins Gilman who was one of the principal speakers at the final meeting of the Walt Whitman Fellowship in 1919, choosing as her subject Whitman's views on women. One wonders what Whitman's reaction would have been to a feminist ideal that took mothers from their homes and children, he who in Democratic Vistas had called for "a new founded literature [that] as perhaps the most precious of its results" would insure to the nation "a strong and sweet Female Race, a race of perfect Mothers. . . " Why was this arch feminist among the speakers at the Fellowship, and what connection could there have been between her philosophy and Whitman's? With no precise knowledge of what Gilman said on that occasion (the text of the address has not been found), all that can be done in an attempt to answer is to trace the connecting tissue of events, people, and ideas that led to the occasion.

The first tenuous connections between Gilman and Whitman were remote ones, involving others more directly than they themselves. Nellie Tarr O'Connor, wife of Whitman's great champion, was aunt to Grace Ellery Channing, the woman to whom Gilman refers in the foreword of her autobiography as "my more than sister." So close were these two women that when Gilman and her first husband Walter Stetson divorced in 1893 and Walter promptly married Grace, the friendship was not affected. Grace Channing's parents had offered the comfort of their California home to William Douglas O'Connor in 1887 when he was suffering with a variety of illnesses. Just a year later they did all in their power to help establish Charlotte Gilman (then Stetson) who, with her daughter Kathryn, had moved to Pasadena from Rhode Island for a trial separation from her husband. 
That separation came after the events so terrifyingly fictionalized in "The Yellow Wall-Paper," Charlotte's mental collapse following the birth of the child and her (mis?)treatment by Dr. S. Weir Mitchell. The story was first published in 1892 in The New England Magazine, and in 1899 Small, Maynard \& Co., who had already published Women and Economics, brought it out as a small volume. The publishers then are the next connecting link between Gilman and Whitman, for it was to Small \& Maynard that Whitman's literary executors committed his works. Small \& Maynard were also the source for Grace Channing's volume of poems, Sea-Drift (named for Whitman's collection of sea poems) that was published at the same time as The Yellow Wallpaper. Included among the poems was one written in Italy where Grace Channing was at the time of Whitman's death. Titled "The Voiceless Syllables of Grass," the poem gracefully contrasts the laurel, symbol of Italy's golden past, with Whitman's symbol, "The common herb One taught to sing." Horace Traubel noticed both volumes in The Conservator of March 1899 with a very positive review of Charlotte Perkins Stetson's The Yellow Wallpaper on one page, faced by Grace Channing Stetson's poem on Whitman on the other. (Charlotte did not acquire the name Gilman until her marriage to George Houghton Gilman in 1900.) $)^{2}$ The year before, The Conservator had highlighted two of Gilman's poems from her published collection called In This Our World, which Traubel urged his readers to get either at a bookstore or library. ${ }^{3}$

Traubel was far more aware of Charlotte, however, than he was of Grace. The reason was simple: Charlotte had moved from being a convert in 1890 to the Nationalists' cause, to being in 1896 a confirmed Socialist and delegate to the International Socialist and Labor Congress in London. To facilitate her increased activities in the Socialist movement, she had, in 1894, sent their daughter to her ex-husband just before his marriage. Her exhusband married Grace, who then assumed in practice the duties of motherhood that Charlotte espoused in theory.

Again and again in the years following this abdication of responsibility, Gilman, who earned much of her reputation and her livelihood from the speaker's lectern, unhesitatingly spoke her thoughts on "The New Motherhood." An abstract of her lecture on the subject that appeared in the first volume of The Forerunner, the periodical Gilman wrote and published from 1910 to 1916, encapsulates the standards of The New Motherhood:

First: The fullest development of the woman, in all her powers, that she may be the better qualified for her duties of transmission by inheritance; Second: The fullest education of the woman ... concerning her great office and in her absolute duty of right selection-measuring the man who would marry her by his fitness for fatherhood ... Third: Intelligent recognition that child culture is the greatest of arts. . . .4

This, then, is the ground on which finally Gilman and Whitman meet, 
the glorification of the female as mother. Like Whitman, Gilman had little interest in women's suffrage; indeed, her interest in economics and what is now called sociology was all predicated on her belief that once freed from the confines of the home and made economically independent through their own labor, women would no longer feel obliged to choose husbands for economic reasons and could engage in selective mating. Such selective mating, she believed, would produce a higher civilization which women would acculturate. Though not so cosmic as Whitman's, it was a vision of perfect motherhood deeply akin to his. With what joy Gilman must have read Whitman's words in Democratic Vistas, “. . . I promulge new races of Teachers, and of perfect Women, indispensable to endow the birth-stock of a New World." 5 As another feminist admirer of Whitman, Mabel MacCoy Irwin, urged women to heed the poet's call and awaken to the need for what she termed a "Justified Motherhood," so Gilman developed the idea of The New Motherhood which demanded the full development of a woman's mental and physical powers, these to be brought to bear on the all-important selection of a father for her children.

Later, in the pages of The Forerunner, Gilman gave fictional form to this idealization in her Utopian myth, Herland, a picture of an all-female welfare state in which the highest welfare is that of its future citizens. It was during the years she published The Forerunner that Gilman came into contact with Whitmanites, though in 1919 she claimed, "When for some years my personal possessions were limited to one trunk [this would have been in the first years after her divorce] I carried two books always: Olive Schreiner's 'Dreams' . . . and Whitman the Great."6 Oddly enough, it was the Canadian disciples of Whitman to whom she became attached, that second generation of Whitmanites who after the death of Dr. Richard M. Bucke found their leadership in the feminist Flora MacDonald Dennison.

Dennison, a Gilman counterpart in the Canadian feminist movement, had a deep and sustained appreciation for Whitman. The last years of her life, from 1910 to her death in 1921, were devoted to fostering the Whitmanite movement in Canada. In 1910 she purchased "Bon Echo," a large tract of land, now a public park, in Peterborough, Ontario, where the Whitman followers had summer houses, and where Whitman was extolled at meetings devoted to his life and work. A huge hanging cliff that juts out over a lake there was dubbed "Old Walt," and here might be found of a summer Traubel, Henry S. Saunders - and Charlotte Perkins Gilman, who visited in 1918 and perhaps sooner. In the June 1916 Forerunner Gilman speaks glowingly of the summer community, claiming to have been there, and urges on her readers the periodical Flora MacDonald edited for the Whitman Club, The Sunset of Bon Echo. In the same year MacDonald refers, in the pages of Sunset, to "The Gilman Cottage" at Bon Echo, adding that Charlotte is "always welcome." 
The Whitman Club at Bon Echo was probably the final link in the chain of events, people, and ideas that led to Charlotte Perkins Gilman's participation in the last meeting of the Walt Whitman Fellowship in 1919. She was Mrs. Houghton Gilman by then, living with her husband in New York City while still working steadily for feminist and Socialist causes. Horace Traubel admired her greatly and no doubt it was he who invited her to speak at the Whitman Centenary. Judging by David Karsner's description of that night, Gilman must have been right at home. The after-dinner speeches had "a distinctly revolutionary flavor," Karsner says, with applause for the mention of such names as Eugene V. Debs and Emma Goldman. ${ }^{8}$ Traubel, sick as he was, relished every moment.

That summer Traubel insisted on traveling to Bon Echo for the Whitman Club's centenary celebration in August for which he had written a poem, "Walt, at Bon Echo, August 1919."9 Charlotte Gilman had also written a small piece, called simply "Walt Whitman," that appeared in the summer issue of The Sunset of Bon Echo. In it she makes the point that Whitman's is the poetry that meets one's maturity when "besides music and emotion, we want thought, vision, strength in poetry." 10 Though Traubel died at Bon Echo in September of 1919 and Gilman lived on until 1935, they had shared in their lifetimes that maturity of poetic sensibility described by Gilman. Still, when one thinks of Traubel telling of the special appeal mothers always had for Whitman, how he spoke of the beauty and inspiration to be found in the sight of "a hale old woman, full of cheer as of years, who has raised a brood of hearty children," one wonders what he would have made of Gilman's "New Motherhood."11

\section{Hofstra University}

\section{NOTES}

1 Walt Whitman, Prose Works 1892, ed. Floyd Stovall (New York: New York University Press, 1964), 2:372.

2 Gilman's ancestry included the illustrious New England Beechers and Edward Everett Hale, whose review of Leaves of Grass in the North American Review for January 1856 was one of the few friendly early reviews Whitman received.

3 Horace Traubel, "Reviews," The Conservator, 9 (August 1898), 109.

4 C. P. Gilman, "The New Motherhood," The Forerunner, 1 (December 1910), 17.

5 Prose Works, 2:364.

6 C. P. Gilman, "Walt Whitman," The Sunset of Bon Echo, 3 (Summer 1919), 28.

7 Flora MacDonald Dennison, "Short Stories," The Sunset of Bon Echo, 1 (March 1916), 17. 
8 David Karsner, Horace Traubel, His Life and Work (New York: Egmont Arens, 1919), pp. 25-26.

9 Karsner, p. 28.

10 C. P. Gilman, "Walt Whitman," 28.

11 Horace Traubel, With Walt Whitman in Camden (Boston: Small, Maynard \& Co., 1906), 1:332. 